\title{
The Discovery of Preproinsulin in 1975
}

Hans E Weber

UCLA-OliveView Medical Center, USA.

*Corresponding Author: Hans E Weber, UCLA-OliveView Medical Center, USA.

Received date: May 13, 2021; Accepted date: May 25, 2021; Published date: May 28,2021

Citation: Hans E Weber. (2021) The Discovery of Preproinsulin in 1975. Clinical Research and Clinical Trials. 3(4); DOI: 10.31579/2693-

4779/044

Copyright: () 2021 Hans E Weber. This is an open access article distributed under the Creative Commons Attribution License, which permits unrestricted use, distribution, and reproduction in any medium, provided the original work is properly cited.

Exactly 100 years ago insulin was discovered - What a lifesaving peptide! Banting and Macleod received the Nobel Prize in 1923. Since then proinsulin was found and then in 1975 preproinsulin was discovered by this author. The rather interesting story as to how this peptide was found is revealed here. Why so many decades later is also told.

In July of 1973 I was given a two year NIH sponsored research fellowship in Immunology at UCLA. My project in Immunology was to translate mRNA from pure $\mathrm{T}$ cell lines to see whether the $\mathrm{T}$ cell receptor had any immunoglobulin component.

My fellow PhDs taught me how to isolate mRNA and translate it in an in vitro system. This was a fairly new technique at that time. While proceeding with this work, I immediately had the novel idea to translate insulin. Why insulin?

While a fellow at the Joslin Clinic in 1971, I had written hundreds of insulin orders. I had to work secretly at night, my excitement was great. Bovine pancreatic tissue from a slaughterhouse in Los Angeles was fairly quickly harvested by myself. My colleagues at UCLA warned me that I may never succeed due to the rapid degradation. I proved them wrong. That was the first milestone.

I authored an Abstract which was published and posted at the 1974 FASEB meeting (1). Later on, I used rabbit and rat islet preparations, readily available at UCLA, to continue my work on the translation of mRNA for insulin. In all of these experiments, a larger peptide than proinsulin was found. That was the second milestone.

In the winter of 1974/75 I submitted an abstract to the American Diabetes Association outlining this work (2).

I was invited to give a ten minute talk in June of 1975 to further outline my work at the Annual Meeting of the ADA.

To my surprise, there were two other ten minute talks scheduled where the presenters had completed similar work, using different animals to mine and came to the same conclusion that there is a precursor present larger than proinsulin. Neither one ever mentioned preproinsulin (they had publications in late 1975 or 1976) (3-6). Therefore, I claim, to have given the name preproinsulin. It was during my talk at the above meeting, although no record exists.

Why was I able to coin the word preproinsulin?

Between January and June of 1975, I had ample time to conduct further experiments. I was convinced that this larger peptide must be a precursor of proinsulin. Logic told me to name it preproinsulin. This name "stuck" and is now widely used.

Other strange and very unfortunate events ensued. After my talk in New York in June of 1975, Dr. Donald F. Steiner, who is always quoted as the discoverer of proinsulin in 1967, approached me and invited me to have dinner with him that evening. He questioned me extensively about my research.

Upon my return to Los Angeles, I began a clinical fellowship in Rheumatology at UCLA.

I had made the decision to leave academic medicine and research because of a rather disgusting event: My collaborator in immunology at UCLA confessed he never actually did any of the experiments, rather he made them up. This was such a shock for me, I left academic medicine. Sadly enough, this is why there are no files remaining.

In 1999 my interest was re-awakened after learning that Professor Blobel had won the Nobel Prize for his signal theory. It took another ten years before I realized just how important my discovery was. It was fascinating to observe that preproinsulin had become an important peptide to study transcription and translation. A new field of research had opened up. Could I have seen this in 1975 while I was thinking about what could be done with my discovery? I had no idea that Professor Blobel at that time dreamed up why this "pre" was necessary.

In June of 1976, Dr. Steiner et al published in PNAS an article (7) utilizing my techniques to translate mRNAfrom rat pancreatic tissue. They arrived at the same conclusion as I that there is a precursor. They name a partial list of the amino acids making up the "pre" and then state in their abstract that they "designate" this molecule preproinsulin. I am referenced under 17 in their article.

Unfortunately, Dr. Steiner omits in his article that he had spoken to me exactly one year prior. 35 years later in a lecture Dr. Steiner states, that in 1975 he directed his $\mathrm{PhD}$ fellow to drop everything immediately and to begin working on "the more pressing problem characterizing preproinsulin" (8).

I believe, however, the train had left the station.

\section{References}

1. In vitro translation of messenger RNA coding for proinsulin; Hans E. Weber and Paul A. Singer SPON: H. E. Weimer. (1974) UCLA School of Medicine, Los Angeles, CA 90024 Abstract;33 (3):275 FASEB, April 1974Atlantic City

2. Partial Prurification and Translation of Proinsulin Messenger 
RNA Hans E. (1975) Weber, Los Angeles, Ca. (Introduced by Mayer B. Davidson, Los Angeles, Ca.). Weber,H.E. Diabetes 24,405

3. Isolation of Biologically Active Fish Islet Messenger RNA by Oligopol-dT Cellulose Affinity Chromatography. (1975) M.A.Permutt, and I. Biome, St. Louis, Missouri. Diabetes 24,405

4. Cell-Free Translation of Panceatic mRNA: (1975) Synthesis of Immunoreactive Insulin. Peter T. Lomedico, Houston, Texas (Introduced by Harold L. Dobson, Houston, Texas) Diabetes 24,405

5. Lomedico,P.T, and Saunders, G.F: (1976) Preparation of pancreatic mRNA: Cell-free translation of an insulin- immunoreactive polypeptide. Nucleic Acids 3:381-91.

6. Permutt, M.A.,Biesbroeck, J.,Chyn, R.,Boime,I.,Szczesna,E., and McWilliams, D. (1976) Isolation of a biologically active messenger RNA: Preparation from fish pancreatic islets by oligo (2'-deoxythymidylic acid) affinity chromatography. In Polypeptide Hormones: Molecular and Cellular Aspects. Ciba Found. Symp. 41. Amsterdam, Elsevier/Excerpta Medica/NorthHolland, pp. 97-116

7. Cell-free synthesis of Rat preproinsulin: (1976) characterization and partial amino acid sequence determination SJ Chan, P Keim and DF Steiner PNAS Vol.73,No.6, pp.1964-1968.

8. Donald F. Steiner (2011) Adventures with Insulin in the Islets of Langerhans J.Biol.Chem.20;286(20):17399-17421
This work is licensed under Creative Commons Attribution 4.0 License

\section{To Submit Your Article Click Here: Submit Manuscript}

DOI: $10.31579 / 2693-4779 / 044$
Ready to submit your research? Choose Auctores and benefit from:

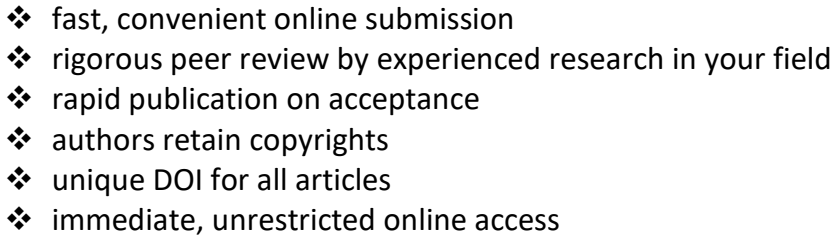

At Auctores, research is always in progress.

Learn more www.auctoresonline.org/journals/clinical-research-andclinical-trials- 